\title{
Colour Intensity, Polyphenol Content and Antibacterial Capacity of Unheated and Heat-Treated Sahara Honey
}

\author{
Moussa Ahmed ${ }^{1,2 *}$, Baghdad Khiati' ${ }^{2}$, Saad Aissat ${ }^{1,2}$ and Noureddine Djebli ${ }^{1}$ \\ ${ }^{1}$ Pharmacognosy and Api-Phytotherapy Research Laboratory, Mostaganem University, Algeria
}

${ }^{2}$ Institute of Veterinary Sciences, University Ibn-Khaldoun, Tiaret, Algeria

\begin{abstract}
The objective of this research work was to evaluate the effect of heat processing on antibacterial capacity of Sahara honey (SH). Various thermal treatments were carried out at $25^{\circ} \mathrm{C}, 50^{\circ} \mathrm{C}, 75^{\circ} \mathrm{C}$ and $100^{\circ} \mathrm{C}$ for $15 \mathrm{~min}, 30 \mathrm{~min}$, and $60 \mathrm{~min}$, and the parameters were determined: colour intensity, phenolic contents and antibacterial activity of two species of bacteria (Staphylococcus aureus and Pseudomonas aeruginosa). The total phenolic contents in honey samples varied from 0.55 and $1.54 \mathrm{mg}$ of gallic acid equivalent (GAE) in gram of honey. MIC values respectively 3.12 to $12.5 \mathrm{mg} / \mathrm{ml}$ and zone of growth inhibition respectively $2.65 \mathrm{~mm}$ to $19 \mathrm{~mm}$. Exposures of $\mathrm{SH}$ at $75^{\circ} \mathrm{C}$ and $100^{\circ} \mathrm{C}$, no inhibition of Staphylococcus aureus and Pseudomonas aeruginosa growth was detected. Statistical analysis demonstrated positive correlations between color intensity and polyphenol contents and negative correlations with antibacterial capacity. Data from present results revealed that unheated and heat-treated Sahara honey showed growth inhibitory effect against Staphylococcus aureus and Pseudomonas aeruginosa with variable degrees.
\end{abstract}

Keywords: Sahara honey; Antibacterial capacity; Thermal processing

\section{Introduction}

Therapy of infections caused by gram-negative and gram-positive negative pathogen is a frequent problem due to the emergence of bacterial strains resistant to numerous drugs [1-3]. Recently many different bacteria now exhibit multi-drug resistance, including Staphylococci sp and Pseudomonas aeruginosa. Bee's products are believed to be an important source of new natural substances with potential therapeutic effects. Recently, the potent activity of honey against antibiotic-resistant bacteria has further increased the interest for application of honey. Several honeys have been approved for clinical application [4-6]. A review of different antibacterial studies showed that the antibacterial properties of honey depend on the geographical origin of the honey [7] Honey bees has been traditionally recognized as valuable source of energy which contains antibacterial and antifungal proprieties [8]. Several bioactive compounds have been identified in honey which contributed to its antibacterial action. In many studies, the presences of peroxide and non-peroxide antibacterial capacity in honey have been reported $[9,10]$. The presence of hydrogen peroxide generated by enzymatic activity of glucose oxidase in diluted honey is considered as the major antibacterial factor [11]. Furthermore, heating honey inactivates the glucose and it oxidates phenolic compounds as important factors for the non-peroxide antibacterial activity of honey [10]. The non-peroxide antibacterial activity is insensitive to heat and light [12]. Several authors also studied the correlations between color and antibacterial activities with content of the bioactive compounds of honey. Various studies have been conducted to investigate the antimicrobial effects [13-15]. Limited studies have been done on Algerian honey. Current analysis assessed the antibacterial activities and the content of colour intensity, phenolic contents in 3 honey samples.

\section{Materials and Methods}

\section{Sample collection}

Three honey samples were collected in Sahara from Algeria during the year 2012. The samples were stored at $4^{\circ} \mathrm{C}$ until analysis in dark conditions.

\section{Thermal treatment}

The SH were heated at $25^{\circ} \mathrm{C}, 50^{\circ} \mathrm{C}, 75^{\circ} \mathrm{C}$ and $100^{\circ} \mathrm{C}$ for $15 \mathrm{~min}, 30$ min and 60 minutes. Then they were cooled down to $4^{\circ} \mathrm{C}$ by immediately plunging the tubes in an ice bath and analyzed. The samples were filled into watertight tubes.

\section{Colour intensity: $\mathrm{ABS}_{720-450}$}

The net absorbance of the $\mathrm{SH}$ was determined by the method of Beretta et al. [16] The SH were diluted to $50 \%$ (w/v) with warm $\left(45^{\circ} \mathrm{C}\right.$ to $50^{\circ} \mathrm{C}$ ) milli Q water and the solution was filtered through a $0.45 \mathrm{~lm}$ filter. There was a complete absence of coarse particles in the honey solutions as all the commercial samples were no crystalline liquid honeys. The absorbance was measured using a spectrophotometer at $450 \mathrm{~nm}$ and $720 \mathrm{~nm}$ and the difference in absorbance was expressed as $\mathrm{mAU}$.

\section{Determination of total phenolic content (TPC)}

Foline Ciocalteu method was used to assay total phenolic contents, which was described by Singleton et al. [17]. Thirty microlitre of honey solution $(0.1 \mathrm{~g} / \mathrm{ml})$ was mixed with $2.37 \mathrm{ml}$ of milli Q water and $150 \mu \mathrm{l}$ of $0.2 \mathrm{~N}$ Folin-Ciocalteu reagents. The solution was thoroughly mixed by vortexing and incubated for $2 \mathrm{~min}$ at ambient temperature. Four hundred and fifty microlitre of sodium carbonate solution $(0.2 \mathrm{~g} / \mathrm{ml})$ was added to the reaction mixture and further incubated for $2 \mathrm{~h}$ at ambient temperature. The absorbance was measured at $765 \mathrm{~nm}$ using a spectrophotometer. The total phenolic content was determined by comparing with a standard curve prepared using gallic acid $(0-200$ $\mathrm{mg} / \mathrm{l})$. The mean of at least three readings was calculated and expressed as $\mathrm{mg}$ of gallic acid equivalents (mg GAE)/100 $\mathrm{g}$ of honey.

*Corresponding author: Moussa Ahmed, Pharmacognosy and Api-Phytotherapy Research Laboratory, Mostaganem University, Algeria, Tel: +213-65234059, Fax: +213-46-425001; E-mail: moussa7014@yahoo.fr

Received May 13, 2016; Accepted June 02, 2016; Published June 07, 2016

Citation: Ahmed M, Baghdad K, Aissat S, Djebli N (2016) Colour Intensity, Polyphenol Content and Antibacterial Capacity of Unheated and Heat-Treated Sahara Honey. J Food Process Technol 7: 589. doi:10.4172/2157-7110.1000589

Copyright: ( 2016 Ahmed M, et al. This is an open-access article distributed under the terms of the Creative Commons Attribution License, which permits unrestricted use, distribution, and reproduction in any medium, provided the original author and source are credited. 
Citation: Ahmed M, Baghdad K, Aissat S, Djebli N (2016) Colour Intensity, Polyphenol Content and Antibacterial Capacity of Unheated and HeatTreated Sahara Honey. J Food Process Technol 7: 589. doi:10.4172/2157-7110.1000589

Page 2 of 5

\section{Antibacterial capacity assays}

\section{Bacterial strains and culture conditions}

Bacterial strains: S. aureus (ATCC 25922) and P. aeruginosa ATCC 27853 bacteria were selected for antibacterial activity assay. The cultures of bacteria were maintained in their appropriate agar slants at $4^{\circ} \mathrm{C}$ throughout the study and used as stock cultures.

Preparation of standard inoculums: Bacteria were routinely grown in Nutrient Agar (NA; Merck Germany) slant, incubated at $37^{\circ} \mathrm{C}$ for $24 \mathrm{~h}$, and kept at $4^{\circ} \mathrm{C}$ until further use. Bacterial suspensions were prepared by inoculating one loopful of the 24 -h-old bacterial colonies into $10.0 \mathrm{ml}$ of sterilized distilled water. The inoculums size was adjusted to match the turbidity of McFarland 0.5 scale $\left(1 \times 10^{8}\right.$ cells $/ \mathrm{ml}$ ) and diluted with sterilized distilled water to the inoculums size of $1 \times 10^{7}$ cells $/ \mathrm{ml}$.

Agar well diffusion method: Antibacterial assay was carried out by modified method of Ahmed et al. [18]. Nutrient agar plates (Merck, Germany) were inoculated by rubbing sterile cotton swabs that were dipped into bacterial suspensions (overnight) cultures grown at $37^{\circ} \mathrm{C}$ on nutrient agar and adjusted to $0.5 \mathrm{McF}$ arland in sterile saline) over the entire surface of the plate. After inoculation $8.2 \mathrm{~mm}$ diameter wells were cut into the surface of the agar using a sterile cork borer. $50 \mu \mathrm{l}$ of test honey was added to each well. Plates were incubated at $30^{\circ} \mathrm{C}$ for $24 \mathrm{~h}$. Zones of inhibition were measured using a Vernier caliper. The diameter of zones, including the diameter of the well, was recorded. Values are given as mean and standard deviation (SD) of tests performed in triplicate. The results were expressed in terms of the diameter of the inhibition zones: $<5.5 \mathrm{~mm}$, inactive; $5.5-9 \mathrm{~mm}$, very low activity; $9-12 \mathrm{~mm}$, low activity; $12-15 \mathrm{~mm}$, average activity; and $>15 \mathrm{~mm}$, high activity.

Minimum inhibitory concentration (MIC): The antibacterial activity of honey was examined by determining the Minimal Inhibitory Concentration (MIC) using the macro dilution broth technique by Elof [19]. Briefly, Serial 2-fold dilutions of honey were inoculated with $10^{6} \mathrm{CFU} / \mathrm{ml}$ (final concentrations) for each of the microorganism's tested. A bacterial suspension of approximately $5 \times 10^{5} \mathrm{CFU} / \mathrm{ml}$ was inoculated into tubes containing honey at different dilutions and incubated at $37^{\circ} \mathrm{C}$ for $24 \mathrm{~h}$. All MIC values were expressed in $\%(\mathrm{v} / \mathrm{v})$. Bioassay was performed in duplicate and repeated twice.

\section{Data analysis}

Each honey was analyzed in triplicate. Results are shown as mean values and standard deviation. Correlations were established using Pearson's correlation coefficient $(r)$ in bivariate linear correlations $(\mathrm{P}$ $<0.05$ ). All statistical analyses were performed with the Statistica 7.0 software for Windows.

\section{Results}

\section{Color intensity}

The color intensity of the Sahara honey samples ranged from 1.26 to $1.44 \mathrm{mAU}$ (Table 1), the color intensity of the Sahara honey induced by thermal treatments ranged from 1.26 to $1.44 \mathrm{mAU}$ (Table 1), The color of honey differ depending on the floral and geographical origin. Honey's color depends on various factors for example: mineral content, ash content. Besides the, honey colour can also be affected by heat, time of storage [20].

\section{Total polyphenol content (TPC)}

The results obtained showed that the TPC (mg GAE/100 g honey)

\begin{tabular}{|c|c|c|c|c|c|c|}
\hline \multirow[t]{2}{*}{$\begin{array}{c}\text { Température } \\
\left({ }^{\circ} \mathrm{C}\right)\end{array}$} & \multirow[t]{2}{*}{$\begin{array}{l}\text { Time } \\
(\min )\end{array}$} & \multirow[t]{2}{*}{$\begin{array}{c}\text { Sahara honey } \\
\text { samples }\end{array}$} & \multicolumn{2}{|c|}{$\begin{array}{l}\text { Color Intensity } \\
A_{450}-A_{720}\end{array}$} & \multicolumn{2}{|c|}{$\begin{array}{c}\text { Polyphenol contents } \\
\text { (mg/GAE/ } 100 \mathrm{~g} \\
\text { honey) }\end{array}$} \\
\hline & & & Mean & DS & Mean & DS \\
\hline \multirow{3}{*}{ Unheated } & \multirow{3}{*}{$0 \mathrm{~min}$} & $\mathrm{SH} 1$ & 1.26 & 0.09 & 0.551 & 0.002 \\
\hline & & $\mathrm{SH} 2$ & 1.37 & 0.11 & 0.67 & 0.01 \\
\hline & & $\mathrm{SH} 3$ & 1.44 & 0.2 & 1.14 & 0 \\
\hline \multirow{9}{*}{$25^{\circ} \mathrm{C}$} & \multirow{3}{*}{$15 \min$} & $\mathrm{SH} 1$ & 1.46 & 0.2 & 0.587 & 0.001 \\
\hline & & $\mathrm{SH} 2$ & 1.35 & 0.03 & 0.543 & 0.005 \\
\hline & & $\mathrm{SH} 3$ & 1.29 & 0.15 & 0.769 & 0.004 \\
\hline & \multirow{3}{*}{$30 \mathrm{~min}$} & $\mathrm{SH} 1$ & 1.34 & 0.09 & 0.853 & 0.002 \\
\hline & & $\mathrm{SH} 2$ & 1.52 & 0.17 & 0.9015 & 0.009 \\
\hline & & $\mathrm{SH} 3$ & 1.37 & 0.15 & 0.734 & 0.002 \\
\hline & \multirow{3}{*}{$60 \mathrm{~min}$} & $\mathrm{SH} 1$ & 1.01 & 0.56 & 0.598 & 0.002 \\
\hline & & $\mathrm{SH} 2$ & 1.31 & 0.11 & 0.7185 & 0.002 \\
\hline & & $\mathrm{SH} 3$ & 1.38 & 0.06 & 0.778 & 0.016 \\
\hline \multirow{9}{*}{$50^{\circ} \mathrm{C}$} & \multirow{3}{*}{$15 \min$} & $\mathrm{SH} 1$ & 1.25 & 0.04 & 0.8685 & 0.03 \\
\hline & & $\mathrm{SH} 2$ & 1.38 & 0.06 & 0.9265 & 0.03 \\
\hline & & $\mathrm{SH} 3$ & 1.54 & 0.13 & 0.78 & 0.01 \\
\hline & \multirow{3}{*}{$30 \mathrm{~min}$} & $\mathrm{SH} 1$ & 1.24 & 0.05 & 0.8685 & 0.03 \\
\hline & & $\mathrm{SH} 2$ & 1.27 & 0.1 & 0.9265 & 0.03 \\
\hline & & $\mathrm{SH} 3$ & 1.45 & 0.09 & 0.78 & 0.01 \\
\hline & \multirow{3}{*}{$60 \mathrm{~min}$} & $\mathrm{SH} 1$ & 1.25 & 0.07 & 0.668 & 0.035 \\
\hline & & $\mathrm{SH} 2$ & 1.4 & 0.04 & 0.6675 & 0.004 \\
\hline & & $\mathrm{SH} 3$ & 1.51 & 0.16 & 0.7625 & 0.016 \\
\hline \multirow{9}{*}{$75^{\circ} \mathrm{C}$} & \multirow{3}{*}{$15 \min$} & $\mathrm{SH} 1$ & 1.23 & 0.2 & 0.705 & 0.007 \\
\hline & & $\mathrm{SH} 2$ & 1.34 & 0.07 & 0.849 & 0.004 \\
\hline & & $\mathrm{SH} 3$ & 1.51 & 0.18 & 0.8015 & 0 \\
\hline & \multirow{3}{*}{$30 \mathrm{~min}$} & $\mathrm{SH} 1$ & 1.32 & 0.14 & 0.669 & 0.024 \\
\hline & & $\mathrm{SH} 2$ & 1.28 & 0.2 & 0.731 & 0.007 \\
\hline & & $\mathrm{SH} 3$ & 1.58 & 0.19 & 0.88 & 0.011 \\
\hline & \multirow{3}{*}{$60 \mathrm{~min}$} & $\mathrm{SH} 1$ & 1.22 & 0.04 & 0.748 & 0.001 \\
\hline & & $\mathrm{SH} 2$ & 1.32 & 0.07 & 0.958 & 0.032 \\
\hline & & $\mathrm{SH} 3$ & 1.59 & 0.19 & 0.8675 & 0.006 \\
\hline \multirow{9}{*}{$100^{\circ} \mathrm{C}$} & \multirow{3}{*}{$15 \min$} & $\mathrm{SH} 1$ & 1.33 & 0.18 & 1.274 & 0.014 \\
\hline & & $\mathrm{SH} 2$ & 1.41 & 0.18 & 1.247 & 0.009 \\
\hline & & $\mathrm{SH} 3$ & 1.22 & 0.09 & 1.2875 & 0.01 \\
\hline & \multirow{3}{*}{$30 \mathrm{~min}$} & $\mathrm{SH} 1$ & 1.64 & 0.1 & 1.3985 & 0.017 \\
\hline & & $\mathrm{SH} 2$ & 1.77 & 0.17 & 1.541 & 0 \\
\hline & & $\mathrm{SH} 3$ & 1.31 & 0.19 & 1.5 & 0.108 \\
\hline & \multirow{3}{*}{$60 \mathrm{~min}$} & $\mathrm{SH} 1$ & 1.81 & 0.35 & 1.384 & 0.025 \\
\hline & & $\mathrm{SH} 2$ & 1.88 & 0.45 & 1.387 & 0.016 \\
\hline & & $\mathrm{SH} 3$ & 1.43 & 0.27 & 1.4595 & 0.02 \\
\hline
\end{tabular}

Data expressed as mean $\pm S D(n=3)$

Table 1: Color intensity and TPC before and after heat-treatment of $\mathrm{SH}$.

determined by the modified Folin-Ciocalteu method varied greatly among the honey types, as is apparent from Table 1 . In this study the TPC of Sahara honeys is ranged from 0.13 to 1.15 with the mean value of $0.39 \mathrm{~g} / 100 \mathrm{~g}$. The TPC of the Sahara honey induced by thermal treatments ranged from 1.26 to $1.44 \mathrm{mAU}$. The TPC of SH depends on different parameters for example: environmental conditions, harvest season and storage ability.

\section{Antibacterial capacity assays}

Minimum inhibitory concentration (MIC): The MIC of the Sahara honey against the two bacterial strains using the microdilution method is summarized in Tables 2 and 3. Minimum inhibitory concentration (MIC) was used to determine the lowest concentration of honey-in-water solution $(\mathrm{w} / \mathrm{v})$ at which the percentage inhibition is almost $100 \%$ [21,22]. The MIC before and after heat-treatment of SH 
Citation: Ahmed M, Baghdad K, Aissat S, Djebli N (2016) Colour Intensity, Polyphenol Content and Antibacterial Capacity of Unheated and HeatTreated Sahara Honey. J Food Process Technol 7: 589. doi:10.4172/2157-7110.1000589

Page 3 of 5

at $25^{\circ} \mathrm{C}$ and $50^{\circ} \mathrm{C}$ for 15,30 and 60 minutes ranged from $3.12-12.5 \mathrm{~mm}$ (Tables 2 and 3 ).

Agar well diffusion method: $\mathrm{SH}$ were tested for their ability to inhibit growth of S. aureus ATCC 25922 and P. aeruginosa ATCC 27853. The results of the in vitro antibacterial capacity of $\mathrm{SH}$ determined by diameters of inhibition zones (DIZ) are presented in (Table 4). The DIZ produced by the undiluted honeys samples was (14.32 - 16.55) $\mathrm{mm}$. After heat-treatment (at $25^{\circ} \mathrm{C}$ and $50^{\circ} \mathrm{C}$ for 15,30 and $60 \mathrm{~min}$ ) the DIZ ranged from (11-17.67) $\mathrm{mm}$ by $P$. auregenosa to (12.67-27) $\mathrm{mm}$ by $S$. aureus (Table 5). The DIZ of SH with $25 \%$ concentration varied from $(14.33-15) \mathrm{mm}$ by $P$. auregenosa to (10.67-12.33) $\mathrm{mm}$ by $S$. aureus. The DIZ after heat-treatment at $25^{\circ} \mathrm{C}$ and $50^{\circ} \mathrm{C}$ for 15 , 30 and 60 minutes ranged from (7-12.67) $\mathrm{mm}$ by $P$. auregenosa to (2 $21.67) \mathrm{mm}$ by $S$. aureus (Table 6). No inhibition (DIZ=not detectable, $\mathrm{MIC}=$ not detectable) of bacterial growth was observed when honey at $75^{\circ} \mathrm{C}$ or $100^{\circ} \mathrm{C}$.

\section{Discussion}

This is the first report on the changes of colour intensity, polyphenols content and antibacterial capacity of Sahara honeys during thermal processing. Several types of honey are produced in Algeria, where honey production is a traditional practice, well implanted in several regions. The Sahara region is located in the south of Algeria, where, due to its edaphoclimatic conditions and flora diversity, sidr and euphorbe are the principal honey types produced. Large number of honeys from different geographical locations and different botanical origins show growth inhibitory action [23-26]. Several bioactive compounds have been identified in honey which contributed to its antimicrobial proprieties. The intrinsic characteristic of honeys, e.g. high osmolarity, acidity (low $\mathrm{pH}$ ), low water activity, catalase to hydrogen-peroxide ratio, polyphenols, Maillard reaction products and production of hydrogen peroxide, although involved in antibacterial action [27-32]. Two important enzymes known to contribute to the major biological proprieties of honey are bee-origin glucose oxidase and floral-origin catalase [33]. Furthermore, heating honey inactivates the glucose oxidates. Molan [34] reported that honey loses its antimicrobial activity when subjected to heat or exposed to light. Radwan et al. [35] showed that heat exposure in a water bath at a temperature that was not clearly specified, but appeared to be $50^{\circ} \mathrm{C}$ for 10 minutes, had an adverse effect on the antibacterial activity of honey. Moreover, Brudzynski and Kim [36] indicate the antibacterial activity of honey may or may not be affected by heat, age, and storage conditions. Also, Rios et al. [37] studied the effects of extraction, storage conditions and heat treatments on antimicrobial activity of Zanthoxylum fagara honey, and found that, at $40^{\circ} \mathrm{C}$, the antimicrobial activity of the honey was not affected. In addition, Chen et al. [38] observed a decrease in antimicrobial activity in processed honey (heat to $45^{\circ} \mathrm{C}$ for $8 \mathrm{~h}$ ). Polyphenols are another important group of compounds with respect to the appearance and the functional properties of honey [39]. Phenolic content varies between different honeys, and phenolic compounds may contribute to antimicrobial activities in honey [40]. In the studied Sahara honeys, only very small amounts of TPC were present. The literature data indicate that there is a strong positive correlation between honey color and total phenolic content $[41,42]$. In the present study, relationship between phenolic content and colour of Sahara honeys, possibly due to a highly extended conjugated systems, especially when complexed with minerals.

Escuredo et al. [43] have shown that individual phenolic compounds have growth inhibition on a wide range of Gram positive and Gramnegative bacteria. But Ulusoy et al. [44] found that antimicrobial activity was not linearly correlated with total and individual phenolic compounds. In the present study, no relationship between phenolic

\begin{tabular}{|c|c|c|c|c|c|c|c|c|c|}
\hline & \multicolumn{9}{|c|}{ P. aerugenosa ATCC27853 } \\
\hline & \multicolumn{3}{|c|}{ SH1 } & \multicolumn{3}{|c|}{ SH2 } & \multicolumn{3}{|c|}{ SH3 } \\
\hline & 15 & 30 & 60 & 15 & 30 & 60 & 15 & 30 & 60 \\
\hline Unheated & 6.25 & 6.25 & 6.25 & 3.12 & 3.12 & 3.12 & 3.12 & 3,12 & 3.12 \\
\hline $25^{\circ} \mathrm{C}$ & 6.25 & 6.25 & 6.25 & 3,12 & 3.12 & 3.12 & 3.12 & 3,12 & 3.12 \\
\hline $50^{\circ} \mathrm{C}$ & 6.25 & 12.5 & 12.5 & 3.12 & 6.25 & 12.5 & 12.5 & 12.5 & 12.5 \\
\hline $75^{\circ} \mathrm{C}$ & ND & ND & ND & ND & ND & ND & ND & ND & ND \\
\hline $100^{\circ} \mathrm{C}$ & ND & ND & ND & ND & ND & ND & ND & ND & ND \\
\hline
\end{tabular}

Table 2:.Values of minimum inhibitory concentration (MIC\%) of $P$. aerugenosa at different temperatures for different heating times.

\begin{tabular}{|c|c|c|c|c|c|c|c|c|c|}
\hline & \multicolumn{9}{|c|}{ S.aureus ATCC 25922} \\
\hline & \multicolumn{3}{|c|}{ SH1 } & \multicolumn{3}{|c|}{ SH2 } & \multicolumn{3}{|c|}{ SH3 } \\
\hline & $15 \mathrm{~min}$ & $30 \mathrm{~min}$ & $60 \mathrm{~min}$ & $15 \mathrm{~min}$ & $30 \mathrm{~min}$ & $60 \mathrm{~min}$ & $15 \mathrm{~min}$ & $30 \mathrm{~min}$ & $60 \mathrm{~min}$ \\
\hline Unheated & 6.25 & 6.25 & 6.25 & 3.12 & 3.12 & 3.12 & 3.12 & 3.12 & 3.12 \\
\hline $25^{\circ} \mathrm{C}$ & 6.25 & 6.25 & 6.25 & 3.12 & 3.12 & 3.12 & 3.12 & 3.12 & 3.12 \\
\hline $50^{\circ} \mathrm{C}$ & 6.25 & 12.5 & 12.5 & 3.12 & 6.25 & 12.5 & 12.5 & 12.5 & 12.5 \\
\hline $75^{\circ} \mathrm{C}$ & ND & ND & ND & ND & ND & ND & ND & ND & ND \\
\hline $100^{\circ} \mathrm{C}$ & ND & ND & ND & ND & ND & ND & ND & ND & ND \\
\hline
\end{tabular}

Table 3: Show the values of minimum inhibitory concentration (MIC \%) S.aureus at different temperatures for different heating times

\begin{tabular}{|c|c|c|c|c|}
\hline Sahara & \multicolumn{2}{|c|}{ S. aerugenosa ATCC 27853 } & \multicolumn{2}{|c|}{ Undiluted } \\
\hline Honey samples & Undiluted & $\mathbf{5 0 \%}$ & 19 \\
\hline SH1 & 16.67 & 15 & 14.67 & 2,65 \\
\hline SH2 & 17.33 & 14.33 & 10.67 & 21.33 \\
\hline SH3 & 15.67 & 11.33 & \\
\hline
\end{tabular}

Table 4: Means of zone of growth inhibition $(\mathrm{mm})$ of $\mathrm{SH}$ on $P$. aerugenosa and S.aureus using agar-well diffusion assays. 
Citation: Ahmed M, Baghdad K, Aissat S, Djebli N (2016) Colour Intensity, Polyphenol Content and Antibacterial Capacity of Unheated and HeatTreated Sahara Honey. J Food Process Technol 7: 589. doi:10.4172/2157-7110.1000589

Page 4 of 5

\begin{tabular}{|c|c|c|c|c|c|c|c|c|c|c|c|c|c|c|c|c|c|}
\hline \multirow{2}{*}{\multicolumn{2}{|c|}{$\begin{array}{l}\text { Sahara honey } \\
\text { samples }\end{array}$}} & \multicolumn{8}{|c|}{ P. aerugenosa ATCC } & \multicolumn{8}{|c|}{ S.aureus ATCC } \\
\hline & & \multicolumn{4}{|c|}{ Undiluted } & \multicolumn{4}{|c|}{$50 \%$ diluted } & \multicolumn{4}{|c|}{ Undiluted } & \multicolumn{4}{|c|}{$50 \%$ diluted } \\
\hline & & $25^{\circ} \mathrm{C}$ & $50^{\circ} \mathrm{C}$ & $75^{\circ} \mathrm{C}$ & $100^{\circ} \mathrm{C}$ & $25^{\circ} \mathrm{C}$ & $50^{\circ} \mathrm{C}$ & $75^{\circ} \mathrm{C}$ & $100^{\circ} \mathrm{C}$ & $25^{\circ} \mathrm{C}$ & $50^{\circ} \mathrm{C}$ & $75^{\circ} \mathrm{C}$ & $100^{\circ} \mathrm{C}$ & $25^{\circ} \mathrm{C}$ & $50^{\circ} \mathrm{C}$ & $75^{\circ} \mathrm{C}$ & $100^{\circ} \mathrm{C}$ \\
\hline \multirow{3}{*}{ SH1 } & $15 \mathrm{~min}$ & 16.3 & 13 & ND & ND & 15 & 9.67 & ND & ND & 27 & 20 & ND & ND & 17 & 21.67 & ND & ND \\
\hline & $30 \mathrm{~min}$ & 15.7 & 11 & ND & ND & 12.67 & 8.67 & ND & ND & 20 & 19.67 & ND & ND & 3 & 14.67 & ND & ND \\
\hline & $60 \mathrm{~min}$ & 13.5 & 11 & ND & ND & 9.33 & 7 & ND & ND & 14.33 & 12.67 & ND & ND & 10 & 7.33 & ND & ND \\
\hline \multirow[t]{3}{*}{$\mathrm{SH} 2$} & $15 \mathrm{~min}$ & 17.67 & 12.33 & ND & ND & 11.67 & 9.67 & ND & ND & 23.67 & 22.67 & ND & ND & 18.7 & 21.33 & ND & ND \\
\hline & $30 \mathrm{~min}$ & 13.33 & 13.33 & ND & ND & 9.67 & 10.67 & ND & ND & 14.33 & 17 & ND & ND & 2 & 16.67 & ND & ND \\
\hline & $60 \mathrm{~min}$ & 17 & 10.33 & ND & ND & 11 & 7 & ND & ND & 16.67 & 15.33 & ND & ND & 9 & 8.67 & ND & ND \\
\hline \multirow[t]{3}{*}{$\mathrm{SH} 3$} & $15 \mathrm{~min}$ & 12.67 & 13.67 & ND & ND & 11.67 & 10.67 & ND & ND & 26 & 20.33 & ND & ND & 18.33 & 21 & ND & ND \\
\hline & $30 \mathrm{~min}$ & 13.33 & 12.33 & ND & ND & 7 & 10 & ND & ND & 16 & 15 & ND & ND & 2.67 & 17 & ND & ND \\
\hline & $60 \mathrm{~min}$ & 12 & 11.33 & ND & ND & 7.67 & 7.67 & ND & ND & 19 & 12.67 & ND & ND & 9 & 5.67 & ND & ND \\
\hline
\end{tabular}

(ND = not determined)

Diameter of the inhibition zones: $<5.5 \mathrm{~mm}$ : inactive; 5.5-9 mm: very low activity; 9-12 mm: low activity; $12-15 \mathrm{~mm}$ : average activity; and >15 mm: high activity.

Table 5: Means of zone of growth inhibition $(\mathrm{mm})$ of $\mathrm{SH}$ at different temperatures for different heating times, using agar-well diffusion assays.

\begin{tabular}{|c|c|c|c|c|c|c|c|c|c|c|}
\hline & \multicolumn{2}{|c|}{ Unheated } & \multicolumn{2}{|c|}{$25^{\circ} \mathrm{C}$} & \multicolumn{2}{|c|}{$50^{\circ} \mathrm{C}$} & \multicolumn{2}{|c|}{$75^{\circ} \mathrm{C}$} & \multicolumn{2}{|c|}{$100^{\circ} \mathrm{C}$} \\
\hline & Color & TPC & Color & TPC & Color & TPC & Color & TPC & Color & TPC \\
\hline Color & 1 & 0.896 & 1 & -0.639 & 1 & -0.646 & 1 & 0.56 & 1 & -0.958 \\
\hline TPC & 0.896 & 1 & -0.639 & 1 & -0.646 & 1 & 0.56 & 1 & -0.958 & 1 \\
\hline
\end{tabular}

Table 6: Matrix of the correlation between color Intensity and TPC before and after heat-treatment of SH.

content, colour and the antibacterial capacity of Sahara honeys was observed. In this study, the assessment of antibacterial capacity was performed using two techniques. The results showed remarkable differences in the nature of the antibacterial capacity when the two methods were compared. The results shown indicate that the bacterial broth macro dilution method presents higher sensitivity compared to the agar-well assay. In the macro dilution test, the liquid medium allows good mobility for both polar and non-polar molecules, since there is no agar barrier to inhibit the diffusion of the non-polar molecules, such as flavonoids and phenolics.

\section{Conclusion}

In conclusion, our study can be considered as the first report on the antibacterial capacity of Sahara honeys during thermal processing. This preliminary screening is an interesting evaluation of the potential antibacterial capacity of the $\mathrm{SH}$. These results confirm the potential use of SH in natural medicine for the treatment of numerous infectious diseases. However further studies are required to identify and quantify the biologically active components present in the $\mathrm{SH}$, in addition, further tests are needed to confirm these screening results in other in vitro and in vivo assays.

\section{Acknowledgement}

This project was supported by Project CNEPRU, Department of Biology, University-Abdelhamid IBN Badis-Mostaganem, Algeria (Grant No. N ${ }^{\circ}$ F02220120001).

\section{References}

1. Davies J, Davies D (2010) Origins and evolution of antibiotic resistance. Microbiol Mol Biol Rev 74: 417-433.

2. Chang HH, Cohen T, Grad YH, Hanage WP, O'Brien TF, et al. (2015) Origin and proliferation of multiple-drug resistance in bacterial pathogens. Microbiol Mol Biol Rev.

3. Yedery RD, Jerse AE (2015) Augmentation of cationic antimicrobial peptide production with histone deacetylase inhibitors as a novel epigenetic therapy for bacterial infections. Antibiotics 4: 44-61.

4. Haryanto T, Urai K, Mukai J, Sugama, Nakatani T, et al. (2012) Effectiveness of indonesian honey on the acceleration of cutaneous wound healing: an experimental study in mice. Wounds 24: 110-119
5. Nakajima Y, Nakano Y, Fuwano S, Hayashi N, Hiratoko Y, et al. (2013) Effects of three types of Japanese honey on full-thickness wound in mice. Evid Based Complement Alternat Med 3: 504-537.

6. Kamaratos AV, Tzirogiannis KN, Iraklianou SA, Panoutsopoulos GI, Kanellos $\mathrm{IE}$, et al. (2014) Manuka honey-impregnated dressings in the treatment of neuropathic diabetic foot ulcers. Int Wound J 11: 259-263.

7. Al-Waili NS, Salom K, Butler G, Al Ghamdi AA (2011) Honey and microbia infections: a review supporting the use of honey for microbial control. J Med Food 14: 1079-1096

8. Bogdanov S, Haldimann M, LuginbühI W, Gallmann P (2007) Minerals in honey: environmental, geographical and botanical aspects. J Apicult Res 46: 269-275.

9. Brudzynski K (2006) Effect of hydrogen peroxide on antibacterial activities of Canadian honeys. Can J Microbiol 52: 1228-1237

10. Brudzynski K, Abubaker K, St-Martin L, Castle A (2012) Re-examining the role of hydrogen peroxide in bacteriostatic and bactericidal activities of honey. Front Microbiol 2: a213.

11. Brudzynski K, Abubaker K, Miotto D (2012) Unraveling a mechanism of honey antibacterial action: polyphenol/ $\mathrm{H}_{2} \mathrm{O}_{2}$-induced oxidative effect on bacterial cell growth and on DNA degradation. Food Chem 133: 329-336.

12. Bogdanov $S$ (1984) Characterisation of antibacterial substances in honey. Lebensmittel- Wissenschaft und -Technologie 17: 74-76.

13. Huttunen S, Riihinen k, Kauhanen J, Tikkanenkaukanen C (2012) Antimicrobial activity of different Finnish monofloral honeys against human pathogenic bacteria. APMIS

14. Mandal MD, Mandal S (2011) Honey: its medicinal property and antibacterial activity. Asian Pasific J Trop Biomed 11: 154-160.

15. Kwakman PH, Te Velde AA, de Boer L, Vandenbroucke-Grauls CM, Zaat SA, et al. (2011) Two major medicinal honeys have different mechanisms of bactericidal activity. PLoS One 4: e17709.

16. Beretta G, Granata P, Ferrero M, Orioli M, Facino RM, et al. (2005) Standardization of antioxidant properties of honey by a combination of spectrophotometric/fluorimetric assays and chemometrics. Analytica Chimica Acta 533: 185-191

17. Singleton VL, Orthofer R, Lamuela-Raventos RM (1999) Analysis of tota phenols and other oxidation substrates and antioxidants by means of FolinCiocalteu reagent. Methods Enzymol 299: 152-178.

18. Ahmed M, Djebli N, Aissat S, Douichene S (2012) The relationship between fructose, glucose and maltose content with diastase number and antipseudomonal activity of natural honey combined with potato starch. Organic Chem Curr Res 1: 6 
Citation: Ahmed M, Baghdad K, Aissat S, Djebli N (2016) Colour Intensity, Polyphenol Content and Antibacterial Capacity of Unheated and HeatTreated Sahara Honey. J Food Process Technol 7: 589. doi:10.4172/2157-7110.1000589

19. Elof JN (2003) A sensitive quick microplate method effect of usnic acid on mitotic index in root tips of to determine the minimal inhibitory concentration of Allium cepa L. Lagascalia. Planta Med 64: 711-713.

20. Das A, Datta S, Mukherjee S, Bose S, Ghosh S, et al. (2014) Evaluation of antioxidative, antibacterial and probiotic growth stimulatory activities of Sesamum indicum honey containing phenolic compounds and lignans. LWT - Int J Food Sci Tech.

21. Tan HT, Rahman RA, Gan SH, Halim AS, Hassan SA, et al. (2009) The antibacterial properties of Malaysian tualang honey against wound and enteric microorganisms in comparison to manuka honey. BMC Complement Altern Med 9: 34

22. Cooper RA, Jenkins L, Henriques AF, Duggan RS, Burton NF, et al. (2010) Absence of bacterial resistance to medical-grade manuka honey. Eur $\mathrm{J}$ Clin Microbiol Infect Dis 29: 1237-1241.

23. Kwakman PHS, Zaat SAJ (2012) Antibacterial components of honey. IUBMB Life 64: 48-101.

24. Dryden M, Goddard C, Madadi A, Heard M, Saeed K, et al. (2014) Bioengineered surgihoney as an antimicrobial wound dressing to prevent Caesarean wound infection: a clinical and cost-effectiveness study. British J Midwifery 22: 23-27.

25. Dryden M, Goddard G, Madadi A, Heard M, Saeed K, et al. (2014) Surgihoney: a modified honey: in-vitro antimicrobial activity of a novel topical wound care treatment. JGAR 2: 168-172.

26. Meslem A, Aissat S, Djebli N, Khiati B, Ahmed M, et al. (2013) Assessment of colour intensity, polyphenol contents and antibacterial capacity of sahara honeys produced by Apis mellifera. JBAPN 3: 200-207.

27. Israili ZH (2013) Antimicrobial properties of honey. Am J Ther 3: 1075-2765.

28. Taormina PI, Niemira BA, Beuchat LR (2001) Inhibitory activity of honey against foodborne pathogens as influenced by the presence of hydrogen peroxide and level of antioxidant power. Int J Food Microbiol 69: 217-225.

29. Weston RJ (2000) The contribution of catalase and other natural products to the antibacterial activity of honey: Review. Food Chem 71: 235-239.

30. Aljadi AM, Yusoff KM (2003) Isolation and identification of phenolic acids in Malaysian honey with antibacterial properties. Turk J Med Sci 3: 229-236.

31. Kwakman PH, de Boer L, Ruyter-Spira CP, Creemers-Molenaar T, Helsper JP, et al. (2011) Medical-grade honey enriched with antimicrobial peptides has enhanced activity against antibiotic-resistant pathogens. Eur J Clin Microbio Infect Dis 30: 251-257.
32. Brudzynski K, Miotto D (2011) Honey melanoidins: Analysis of a composition of the high molecular weight melanoidin fractions exhibiting radical scavenging capacity. Food Chem 127: 1023-1030.

33. White JW, Subers MH, Schepartz Al (1963) The identification of inhibine, the antibacterial factor in honey, as hydrogen peroxide and its origin in a honey glucose-oxidase system. Biochim Biophys Acta 73: 57-70.

34. Molan PC (1992) The antibacterial activity of honey 2: Variation in the potency of the antibacterial activity. Bee World 73: 59-76.

35. Radwan SS, El-Essaway AA, Sarhan MM (1984) Experimental evidence for the occurrence in honey of specific substances active against microorganisms. Zid Mikrobiol 139: 249-255.

36. Brudzynski K, Kim L (2011) Storage-induced chemical changes in active components of honey de-regulate its antibacterial activity. Food Chem 126 $1155-1163$.

37. Rios AM, Novoa ML, Vit P (2001) Effects of extraction, storage conditions and heating treatment on antibacterial activity of Zanthoxylum fagara honey from Cojedes, Venezuela. Revista Cientifica 11: 397-402.

38. Chen C, Campbell LT, Blair SE, Carter DA (2012) The effect of standard hea and filtration processing procedures on antimicrobial activity and hydrogen peroxide levels in honey. Frontiers in microbiology.

39. Bogdanov S, Jurendic T, Sieber R, Gallmann P (2008) Honey for nutrition and health: A Review. J Am Coll Nutr 27: 677-689.

40. Isla MI, Craig A, Ordoñez R, Zampini C, Sayago BE, et al. (2011) Physico chemical and bioactive properties of honeys from Northwestern Argentina. LWT-Food Sci Technol 44: 1922-1930.

41. Brudzynski K, Miotto D (2010) The relationship between the content of Maillard reaction-like products and bioactivity of Canadian honeys. Food Chem 124 869-874.

42. Sant'Ana LD, Ferreira ABB, Lorenzon MCA, Berbara RRL, Castro RN, et al. (2014) Correlation of total phenolic and flavonoid contents of Brazilian honeys with colour and antioxidant capacity. Int J Food Prop 7: 65-76.

43. Escuredo O, Silva LR, Valentão P, Seijoa MC, Andrade PB, et al. (2011) Assessing rubus honey value: Pollen and phenolic compounds content and antibacterial capacity. Food Chem 130: 671-678.

44. Ulusoy E, Kolayli S, Sarikaya AO (2010) Antioxidant and antimicrobial activity of different floral origin honeys from Turkiye. J Food Biochem 34: 321-335. 